\title{
Coupled use of COSPEC and satellite measurements to define the volumetric balance during effusive eruptions at Mt. Etna, Italy
}

\author{
Andrea M. Steffke a,*, Andrew J.L. Harris a,b, Mike Burton ${ }^{\mathrm{c}}$, \\ Tommaso Caltabiano ${ }^{\mathrm{d}}$, Giuseppe Giovanni Salerno ${ }^{\mathrm{c}, \mathrm{d}}$
}

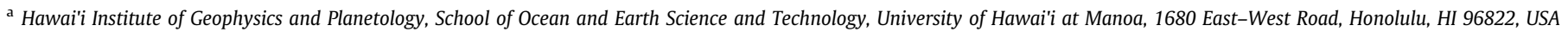

b Laboratorie Magmas et Volcans, Université Blaise Pascal, 5 Rue Kessler, 63038, Clermont-Ferrand, France

c INGV, Catania, Piazza Roma 2, 95123 Catania, Italy

d Department of Geography, University of Cambridge, Downing Place, Cambridge, CB2 3EN, UK
}

Using Etna as a case study location, we examine the balance between the volume of magma supplied to the shallow volcanic system (using ground-based $\mathrm{SO}_{2}$ data) and the volume erupted (using satellite thermal data). We do this for three eruptions of Mt. Etna (Italy) during 2002 to 2006. We find that, during the three eruptions, $2.3 \times 10^{7} \mathrm{~m}^{3}$ or $24 \%$ of the degassed volume remained unerupted. However, variations in the degree of partitioning between supplied $\left(\mathrm{V}_{\text {supply }}\right)$ and erupted $\left(\mathrm{V}_{\text {erupt }}\right)$ magma occur within individual eruptions over the time scales of days. Consequently, we define and quantify three types of partitioning. In the first case, $\mathrm{V}_{\text {supply }}<\mathrm{V}_{\text {erupt }}$, i.e. more lava is erupted than is supplied. In such a case previously degassed magma is erupted or magma can rise faster than it is able to degas, as occurred during the open phases of the 2002-2003 and 2004-2005 eruptions, respectively. In the second case, $V_{\text {supply }}>V_{\text {erupt }}$, i.e. less lava is erupted than is supplied. In such a case, magma can erupt in an explosive manner, as occurred during Phase II of the 2002-2003 eruption, or remain within or below the edifice. In the third case, $\mathrm{V}_{\text {supply }}=\mathrm{V}_{\text {erupt }}$, i.e. all supplied magma is erupted. During 2002-2006, over a total of 280 days of eruptive activity, this balancing case applied to $50 \%$ of the time.

\author{
Keywords: \\ Etna \\ thermal remote sensing \\ $\mathrm{SO}_{2}$ \\ flux \\ mass balance \\ effusive eruptions
}

\section{Introduction}

Satellite remote sensing can be used during effusive eruptions to determine the time-averaged discharge rate at which lava is erupted (e.g., Wright et al., 2001; Harris and Baloga, 2009; Coppola et al., 2010). At the same time, the degassing that takes place as the magma rises to the surface can be measured using ultraviolet spectroscopic methods (e.g., Stoiber et al., 1983; Galle et al., 2002; Yang et al., 2007). While time-averaged discharge rates have been measured using satellite data at Mt. Etna (Italy) on a regular basis since the 1991-1993 eruption (e.g., Harris et al., 1997, 2000; Lautze et al., 2004), sulfur dioxide $\left(\mathrm{SO}_{2}\right)$ fluxes have been derived from correlation spectrometer (COSPEC) measurements on a regular basis since 1987 (e.g. Caltabiano et al., 1994; Allard, 1997; Andronico et al., 2005; Burton et al., 2005). Allard (1997) and Harris et al. (2000) compared time-averaged

\footnotetext{
* Corresponding author. Tel.: +1 808956 0182; fax: +1 8089566322. E-mail addresses: steffke@higp.hawaii.edu (A.M. Steffke), A.Harris@opgc.univ-bpclermont.fr (A.J.L. Harris), burton@ct.ingv.it (M. Burton), ggs25@cam.ac.uk (G.G. Salerno).
}

discharge rates with the measured $\mathrm{SO}_{2}$ fluxes to determine how much of the degassed magma was erupted onto Etna's flanks between 1975 and 1995 , finding that only $10-20 \%$ of the $3.5-5.9 \mathrm{~km}^{3}$ of magma degassed over that period was erupted. However, these studies examined bulk volumes erupted annually rather than examining the short-term variations during eruptions.

Determining the balance between the amount of magma supplied and the amount of lava erupted during an individual eruption remains an unresolved issue, but has implications for our understanding of the excess degassing problem (Andres et al., 1991; Francis et al., 1993; Kazahaya et al., 1994). Excess degassing models tend to envisage unerupted, degassed magma sinking in the conduit to be balanced by ascent of fresh, undegassed magma via conduit convection (e.g., Harris and Stevenson, 1997; Williams-Jones et al., 2003; Witter et al., 2004), with the unerupted degassed volume being intruded within or beneath the edifice (e.g., Dzurisin et al., 1984; Dvorak and Dzurisin, 1993; Allard, 1997; Harris et al., 1999). The main objective of this paper is to examine short-term variations in the partitioning of erupted and unerupted magma volumes using satellite-based timeaveraged discharge rates along with regularly measured $\mathrm{SO}_{2}$ fluxes. 
We use these to assess how and when the volume of magma supplied to the shallow system is balanced by the volume of lava erupted during individual effusive eruptions.

\subsection{Magma volumetric balance: dynamics}

Once magma enters the shallow system three scenarios are possible. In the first scenario, degassed magma can remain unerupted but within the edifice, resulting in endogenous growth (Dzurisin et al., 1984; Dvorak and Dzurisin, 1993). In the second scenario, it can sink back to deeper levels to mix with a deep reservoir or be intruded below the edifice (resulting in cryptic growth) (Allard, 1997; Harris et al., 1999). Alternatively, in the third scenario, it can be erupted onto the surface resulting in exogenous growth (Francis et al., 1993; Sutton et al., 2001). As a result, three different mass balance scenarios can occur: (1) the volume of erupted lava $\left(V_{\text {erupt }}\right)$ can be less than the volume of supplied magma ( $\left.\mathrm{V}_{\text {supplied }}\right)$, meaning that a portion of the degassed magma has not been erupted; (2) $V_{\text {erupt }}$ can be greater than $\mathrm{V}_{\text {supplied, }}$ meaning that previously degassed magma in temporary storage within the shallow system has contributed to the erupted flux, or the magma has risen at a rate faster than it can degas; or (3) $V_{\text {erupt }}$ can equal $\mathrm{V}_{\text {supplied }}$, meaning that all of the degassed magma has been erupted.

These scenarios have been documented at several volcanoes. At Kilauea (Hawaii) between 1956 and 1983, V $V_{\text {supplied }}$ was greater than $\mathrm{V}_{\text {erupted }}$ with $45-65 \%$ of the supplied magma remaining within the volcano's rift zones (Dzurisin et al., 1984; Dvorak and Dzurisin, 1993). In contrast, during 1983-2002 $\mathrm{V}_{\text {supplied }}$ equaled $\mathrm{V}_{\text {erupted }}$ (Dvorak and Dzurisin, 1993; Sutton et al., 2001). At Krafla (Iceland) deformation data revealed an excess in $\mathrm{V}_{\text {supplied }}$ during 1975-1978, resulting in endogenous growth by rift zone intrusion (Bjornsson et al., 1979). At Etna, an excess volume of degassed magma likely resulted in the creation of a cryptic plutonic complex within Etna's sedimentary basement (Allard, 1997), as well as contributing to some endogenous growth by intrusion (Budetta and Carbone, 1998; Harris et al., 2000).

However, most studies have examined volume fluxes over periods of months to decades and have not examined the potential variation in volume partitioning during individual eruptions over the time scale of hours to days. Here we compare the volumes of degassed magma with the amount of erupted lava during three effusive eruptions of contrasting styles and locations at Etna between 2002 and 2006. To do this we use COSPEC-derived $\mathrm{SO}_{2}$ measurements and time-averaged discharge rates obtained from Advanced Very High Resolution Radiometer (AVHRR) thermal data. We show that the balance between the volumes of degassed magma and erupted lava not only vary from eruption to eruption, but also vary during single eruptions.

\section{Etna eruptions: 2002-2006}

Three eruptions occurred at Etna during 126 2002-2006: the 2002-2003 flank eruption, the 2004-2005 flank eruption and the 2006 summit eruption. The 2002-2003 flank eruption began on 26 October 2002 when two eruptive fissures opened on the South and NE flanks (Andronico et al., 2005). The eruption lasted three months ending on 28 January 2003 and was characterized by moderate lava effusion ranging from 2 to $15 \mathrm{~m}^{3} \mathrm{~s}^{-1}$, as well as explosive activity (Andronico et al., 2009). The eruption was preceded by a sharp increase in $\mathrm{SO}_{2}$ emission on 25 October 2002, which increased from a background flux of $1000 \mathrm{t} / \mathrm{d}$ to $2000 \mathrm{t} / \mathrm{d}$ (Andronico et al., 2005). The 2004-2005 flank eruption began on 7 September 2004 with the opening of a fracture on the lower eastern flank of the South East Cone (SEC). The eruption was characterized by low but steady effusion at 2.3-4.1 $\mathrm{m}^{3} \mathrm{~s}^{-1}$ to feed lava flows that extended up to $2.5 \mathrm{~km}$ (Burton et al., 2005; Mazzarini et al., 2005). The eruption lasted 6 months ending in March 2005 (Allard et al., 2006; Bonaccorso et al., 2006).
Unlike most Etnean eruptions no precursory activity, such as an increase in $\mathrm{SO}_{2}$ flux, preceded the eruption (Burton et al., 2005).

The 2006 eruption began on 14 July 2006 when a fissure opened on the east flank of the SEC (Neri et al., 2006; Andronico et al., 2009). The eruption lasted 11 days ending on 24 July. The eruption was characterized by lava flows emplaced at highly variable effusion rates that ranged between 2 and $10 \mathrm{~m}^{3} \mathrm{~s}^{-1}$ and was accompanied by Strombolian activity at SEC. Lava flows had not reached lengths longer than $3 \mathrm{~km}$ when the eruption ended (BGVN, 2006). A second phase of the 2006 eruption commenced on 31 August and continued until 14 December. This portion of the eruption was characterized by intense explosive activity and hence is not examined in this work (Behncke et al., 2005; Andronico et al., 2009).

\section{Methodology}

We calculated magma degassing rates and volumes of magma degassed using COSPEC-derived $\mathrm{SO}_{2}$ measurements. Previous studies have shown how $\mathrm{SO}_{2}$ flux can be measured using COSPEC and that, using $\mathrm{SO}_{2}$ flux, the volume of degassed magma can be calculated (Allard, 1997; Caltabiano et al., 2004; Allard et al., 2006):

$Q_{d}\left(m^{3}\right)=Q_{s} /\left[(S)^{*} \rho^{*}(1-X)\right]$

where $Q_{d}$ is the volume of degassed magma, $Q_{s}$ is the volume of elemental sulfur, $S$ is the weight fraction of sulfur degassed per unit of magma, $X$ is the crystal fraction and $\rho$ is the density of the magma. The $\mathrm{SO}_{2}$ source is degassing magma, ascending toward the surface. Melt inclusion studies (Metrich et al., 2004; Spilliaert et al., 2006) have constrained the original sulfur content of Etnean magma to be $\sim 0.32$ wt.\%. Using this value we can calculate the amount of $\mathrm{SO}_{2}$ a specific volume of unvesiculated primitive magma can produce. All values used to calculate magma volume and thus supply rates are given in Table 1.

For each of the eruptions considered here $\mathrm{SO}_{2}$ measurements were made daily (Andronico et al., 2005; Burton et al., 2005). We then used these measurements to calculate the degassed magma flux (in $\mathrm{m}^{3} \mathrm{~s}^{-1}$ ). We use this to define the amount of magma that is degassed over a given time period, in this case a day, and term this time-averaged (daily) magma supply rate $\left(S_{r}\right)$. Given $S_{r}$ we can integrate through time to calculate the volume of degassed magma over each measurement period. We term this the volume of supplied magma ( $\left.\mathrm{V}_{\text {supplied }}\right)$ (Table 2). Errors associated with the $\mathrm{SO}_{2}$ method have been shown to range between 20 and 30\% (Caltabiano et al., 2004; Andronico et al., 2005). In this study we assume the maximum error of $\pm 30 \%$ and calculate a range of $S_{r}$ and $V_{\text {supplied }}$ using this uncertainty.

Table 1

Parameters, values and supporting references for constants used in calculating discharge and supply rate.

\begin{tabular}{lll}
\hline Parameter & Value & Reference \\
\hline $\mathrm{T}_{\text {surf }}\left({ }^{\circ} \mathrm{C}\right)$ & $100-500$ & Harris et al. (2000) \\
$\mathrm{T}_{\text {amb }}\left({ }^{\circ} \mathrm{C}\right)$ & 0 & Harris et al. (2000) \\
$\sigma\left(\mathrm{W} \mathrm{m}^{-2} \mathrm{~K}^{-4}\right)$ & $5.67 \times 10^{-8}$ & Harris et al. (2000) \\
$\mathrm{h}_{\mathrm{c}}\left(\mathrm{W} \mathrm{m}^{-2} \mathrm{~K}^{-1}\right)$ & $\sim 10$ & Harris et al. (2000) \\
DRE $\rho\left(\mathrm{kg} \mathrm{m}^{-3}\right)$ & 2600 & Harris et al. (2000) \\
DRE $\mathrm{c}_{\mathrm{p}}\left(\mathrm{J} \mathrm{kg}^{-1} \mathrm{~K}^{-1}\right)$ & 1150 & Harris et al. (2000) \\
Vesicularity & $10-34$ & Harris et al. (2000) \\
Bulk $\rho\left(\mathrm{kg} \mathrm{m}^{-3}\right)$ & $1720-2340$ & Harris et al. (2000) \\
Bulk c $\left(\mathrm{J} \mathrm{kg}^{-1} \mathrm{~K}^{-1}\right)$ & $810-1035$ & Harris et al. (2000) \\
Cooling range $(\mathrm{K})$ & $200-350$ & Harris et al. (2000) \\
$\phi(\%)$ & 45 & Harris et al. (2000) \\
$\mathrm{C}_{\mathrm{L}}\left(\mathrm{J} \mathrm{kg}{ }^{-1}\right)$ & $3.5 \times 10^{5}$ & Caltabiano et al. (2004) \\
$\mathrm{X}_{\mathrm{c}}$ & 30 & Caltabiano et al. (2004) \\
$\rho_{\mathrm{m}}\left(\mathrm{kg} \mathrm{m}^{-3}\right)$ & 2600 & Caltabiano et al. (2004) \\
\hline
\end{tabular}


Table 2

Definitions, descriptions and significance of parameters used in determining volumetric balance.

\begin{tabular}{|c|c|c|}
\hline Parameter & Description and significance & Derivation \\
\hline $\mathrm{S}_{\mathrm{r}}$ & $\begin{array}{l}\text { Time-averaged (daily) supply rate } \\
\text { of magma. Rate of magma entering } \\
\text { the shallow portion of the system }\end{array}$ & $\begin{array}{l}\text { Calculated by supplied magma } \\
\text { volume flux required to give the } \\
\text { measured } \mathrm{SO}_{2} \text { flux }\end{array}$ \\
\hline$D_{\mathrm{r}}$ & $\begin{array}{l}\text { Time-averaged (daily) discharge } \\
\text { rate of lava. Rate of lava being } \\
\text { erupted from the volcano }\end{array}$ & $\begin{array}{l}\text { Calculated by erupted volume } \\
\text { flux required to balance heat loss }\end{array}$ \\
\hline $\mathrm{V}_{\text {supply }}$ & $\begin{array}{l}\text { Volume of magma degassed over a } \\
\text { given period of time. Volume } \\
\text { supplied to the shallow portion of } \\
\text { the system }\end{array}$ & $\begin{array}{l}\text { Calculated by integrating } \mathrm{S}_{\mathrm{r}} \\
\text { through time }\end{array}$ \\
\hline$V_{\text {erupt }}$ & $\begin{array}{l}\text { Volume of lava erupted over a } \\
\text { given period of time. Volume of } \\
\text { erupted lava }\end{array}$ & $\begin{array}{l}\text { Obtained by integrating } D_{r} \\
\text { through time }\end{array}$ \\
\hline
\end{tabular}

Time-averaged discharge rates were calculated using cloud-free AVHRR data. The pixel mixture model initially proposed by Dozier (1981) and adapted for use with one AVHRR band (Harris et al., 1997) was used; allowing us to determine the area of active lava that occupied each thermally anomalous pixel:.

$\left[\frac{L\left(\lambda, T_{\text {int }}\right)-L\left(\lambda, T_{\text {amb }}\right)}{L\left(\lambda, T_{\text {hot }}\right)-L\left(\lambda, T_{\text {amb }}\right)}\right] A_{\text {pixel }}=p A_{\text {pixel }}=A_{\text {lava }}$

where $L\left(\lambda, T_{\text {int }}\right)$ is the integrated radiance received at the satellite sensor, $L\left(\lambda, T_{a m b}\right)$ is the radiance of the ambient background at temperature $T_{a m b}, L\left(\lambda, T_{\text {hot }}\right)$ is the radiance of lava at temperature $T_{\text {hot }}$, $A_{\text {pixel }}$ is the area of the pixel, $p$ is the portion of pixel occupied by $T_{\text {hot }}$ and $A_{\text {lava }}$ is the area of lava that has been erupted. Eq. (2) has three unknowns : $T_{a m b}, T_{h o t}$ and $p$. Here we assume $T_{a m b}$ is equivalent to the temperature of lava-free (non-anomalous) surrounding pixels. This leaves two unknowns, $T_{\text {hot }}$ and $p$. Following Harris et al. (1997), $p$ was estimated using a range of possible lava temperatures (Table 1), giving a range of possible $p$ and thus $A_{\text {lava }}$. Values for $A_{\text {lava }}$ obtained for each pixel were then summed to obtain total lava area and used to calculate the radiative and convective heat losses from the active lava ( $Q_{\text {rad }}$ and $Q_{c o n v}$ ) following Oppenheimer (1991).

Heat loss was then converted to effusion using the methodology derived for Etna by Harris et al. (1997, 2000).

$E_{r}=\left(Q_{\text {rad }}+Q_{\text {conv }}\right) / \rho\left(c_{p} \delta T+\phi c_{L}\right)$

where $E_{r}$ is the time-averaged discharge rate, $Q_{\text {rad }}$ is the radiative heat loss, $Q_{\text {conv }}$ is the convective heat loss, $\rho$ is density of the lava, $c_{p}$ is the specific heat capacity, $\delta T$ is the temperature difference from liquidus to solidus, $\phi$ is the fraction of crystals grown in cooling through $\delta T$ and $c_{L}$ is the latent heat of crystallization. All values used to calculate the effusion rates are given in Table 1 . These rates were used to calculate the volume of lava erupted over a given period ( $\mathrm{V}_{\text {erupted }}$ ) (Table 2). Uncertainties associated with this method are of the order of $50 \%$, mostly due to the requirement to assume a range of $T_{\text {hot }}$ and $\delta T$, although when compared with simultaneously measured ground values derived $E_{r}$ are in good agreement (Harris et al., 2007; Harris and Baloga, 2009; Harris et al., 2010). As with the $\mathrm{SO}_{2}$ data, we assume the maximum error and calculate a range of $E_{r}$ and $V_{\text {erupted }}$ using this uncertainty.

\section{Results}

The balance between supplied magma volumes and erupted lava volumes for each eruption is given in Table 3. The temporal variations during each eruption are also plotted in Fig. 1a, with supply versus erupted volume differences $\left(\mathrm{V}_{\text {supply }}-\mathrm{V}_{\text {erupted }}\right)$ being plotted in Fig. 2 . Each eruption can be split into phases based on relative levels of supplied magma volumes and erupted lava volumes, and thus the differences between the two volumes (Figs. 1 and 2). The rates and volumes shown in Fig. 1 and Table 3 were calculated using the full range of errors associated with each method.

The 2002-2003 eruption began with a five-day phase during which $E_{\mathrm{r}}$ exceeded $\mathrm{S}_{\mathrm{r}}$ (Phase I, Fig. 1a), meaning that more lava was erupted than was degassed (Fig. 2; Table 2). As a result, the output exceeded supply (Fig. 1a). However, during the following phase (Phase II), $\mathrm{S}_{\mathrm{r}}$ exceeded $\mathrm{E}_{\mathrm{r}}$ (Fig. 1a; Table 3 ) to cause an excess in magma supplied (Fig. 2). Consequently, the volume of supplied magma greatly surpassed the volume of erupted lava (Fig. 1b). During the third phase (Phase III) $S_{\mathrm{r}}$ equaled $\mathrm{E}_{\mathrm{r}}$ (Fig. 1a); so that $\mathrm{V}_{\text {supplied }}=\mathrm{V}_{\text {erupted }}$ (Fig. 2; Table 3). During the final phase (Phase IV) there was an excess of supplied magma (Fig. 2; Table 3). Overall, during the entire eruption, $V_{\text {supplied }}$ exceeded $V_{\text {erupt }}$ by $3.4 \times 10^{7} \mathrm{~m}^{3}$ (Fig. 1b; Table 3). Field-based measurements of erupted lava during this eruption were measured to be $3.5-4.0 \times 10^{7} \mathrm{~m}^{3}$ (Allard et al., 2006) (assuming a vesicularity of $25 \%$ ). These values fall within the given range of erupted volumes calculated in this study (Fig. 1b).

During the 2004-2005 eruption $E_{\mathrm{r}}$ and $S_{\mathrm{r}}$ were approximately constant throughout the eruption, with periods of small differences (Fig. 1a). We classified the eruption into four phases (Phases A-D). During two of the phases (Phases $A$ and $C$ ), $V_{\text {erupt }}$ exceeded $V_{\text {supplied, }}$ but only by a small amount (Fig. 2; Table 3 ). In the other two phases (Phase $\mathrm{B}$ and $\mathrm{D}$ ), the two volumes were coupled and so that $\mathrm{V}_{\text {supplied }}$ was equal to the $V_{\text {erupted }}$ (Fig. 2; Table 3). The total difference between $V_{\text {erupt }}$ and $V_{\text {supplied }}$ during the entire eruption was $6.6 \times 10^{6} \mathrm{~m}^{3}$. Fieldbased measurements of $V_{\text {erupt }}$ were $5.0 \times 10^{7} \mathrm{~m}^{3}$ (Allard et al., 2006), also falling within the range of volumes calculated in this study (Fig. 1b).

The 2006 eruption was characterized by almost constant $S_{r}$. However, $E_{r}$ was highly variable (Fig. 1a). During the first four days (Phase X), $E_{\mathrm{r}}$ was lower than $\mathrm{S}_{\mathrm{r}}$. However after July 19th 245 (Phase $\mathrm{Y}$ ), $E_{r}$ increased to surpass $S_{r}$ (Fig. 1a; Table 3). Therefore, $V_{\text {supplied }}$ was

Table 3

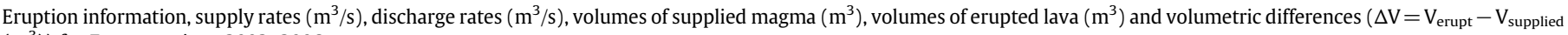
$\left.\left(\mathrm{m}^{3}\right)\right)$ for Etna eruptions 2002-2006.

\begin{tabular}{|c|c|c|c|c|c|c|c|c|c|c|c|c|c|}
\hline \multirow{2}{*}{$\frac{\text { Eruption: }}{\text { Phase: }}$} & \multicolumn{5}{|l|}{ 2002-2003 } & \multicolumn{5}{|l|}{ 2004-2005 } & \multicolumn{3}{|l|}{2006} \\
\hline & I & II & III & IV & Total & A & B & $\mathrm{C}$ & $\mathrm{D}$ & Total & $\mathrm{X}$ & $\mathrm{Y}$ & Total \\
\hline Start date & $26-0 c t-02$ & 31-Oct-02 & 13-Dec-02 & 28-Dec-02 & & 16-Sep-04 & 7-Oct-04 & 4-Nov-04 & 2-Dec-04 & & 15-Jul-06 & 19-Jul-06 & \\
\hline Stop date & $30-O c t-02$ & 12-Dec-02 & 27-Dec-02 & 29-Jan-03 & & 6-Oct-04 & 3-Nov-04 & 1-Dec-04 & 10-Mar-04 & & 18-Jul-06 & 25-July-06 & \\
\hline $\begin{array}{c}\text { Duration } \\
\text { (days) }\end{array}$ & 5 & 42 & 15 & 33 & 95 & 21 & 28 & 27 & 98 & 174 & 4 & 7 & 11 \\
\hline $\operatorname{Max} D_{r}$ & 33 & 9 & 8 & 5 & & 5 & 5 & 6 & 12 & & 5 & 10 & \\
\hline $\operatorname{Max}_{\mathrm{r}}$ & 15 & 22 & 7 & 10 & & 2 & 2 & 4 & 11 & & 4 & 6 & \\
\hline$V_{\text {supply }}$ & $1.6 \times 10^{6}$ & $3.9 \times 10^{7}$ & $5.6 \times 10^{6}$ & $1.4 \times 10^{7}$ & $6.0 \times 10^{7}$ & $1.4 \times 10^{6}$ & $2.4 \times 10^{6}$ & $2.9 \times 10^{6}$ & $2.8 \times 10^{7}$ & $3.5 \times 10^{7}$ & $8.1 \times 10^{5}$ & $1.8 \times 10^{6}$ & $2.6 \times 10^{6}$ \\
\hline$V_{\text {erupt }}$ & $5.9 \times 10^{6}$ & $1.0 \times 10^{7}$ & $5.1 \times 10^{6}$ & $5.3 \times 10^{6}$ & $2.6 \times 10^{7}$ & $4.0 \times 10^{6}$ & $5.9 \times 10^{6}$ & $6.9 \times 10^{6}$ & $2.4 \times 10^{7}$ & $4.1 \times 10^{7}$ & $5.2 \times 10^{5}$ & $2.2 \times 10^{6}$ & $2.7 \times 10^{6}$ \\
\hline$\Delta \mathrm{V}$ & $4.3 \times 10^{6}$ & $-2.9 \times 10^{7}$ & $-5.0 \times 10^{5}$ & $-8.7 \times 10^{6}$ & $-3.4 \times 10^{7}$ & $2.6 \times 10^{6}$ & $3.5 \times 10^{6}$ & $4.0 \times 10^{6}$ & $-4.0 \times 10^{6}$ & $6.1 \times 10^{6}$ & $-2.9 \times 10^{5}$ & $4.0 \times 10^{5}$ & $1.1 \times 10^{5}$ \\
\hline
\end{tabular}



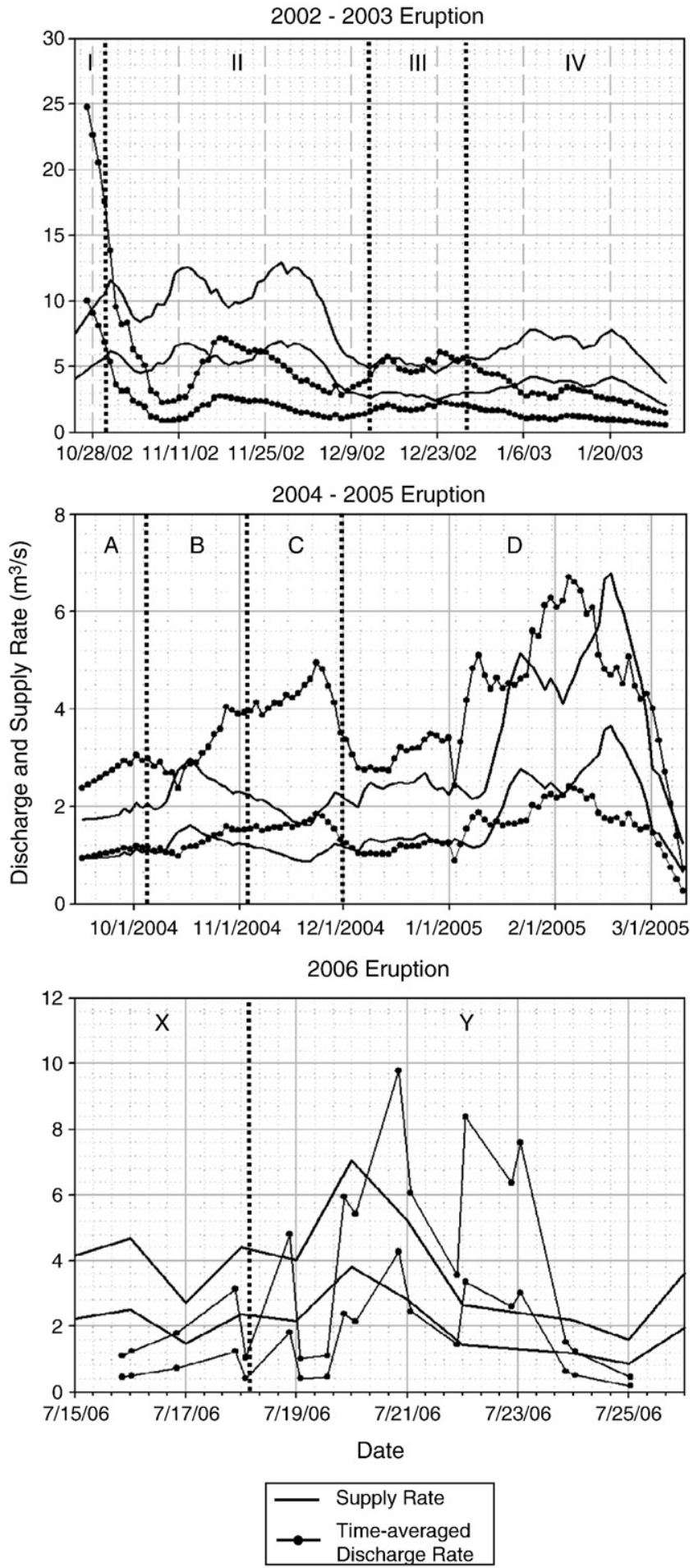

b

Cumulative Volumes
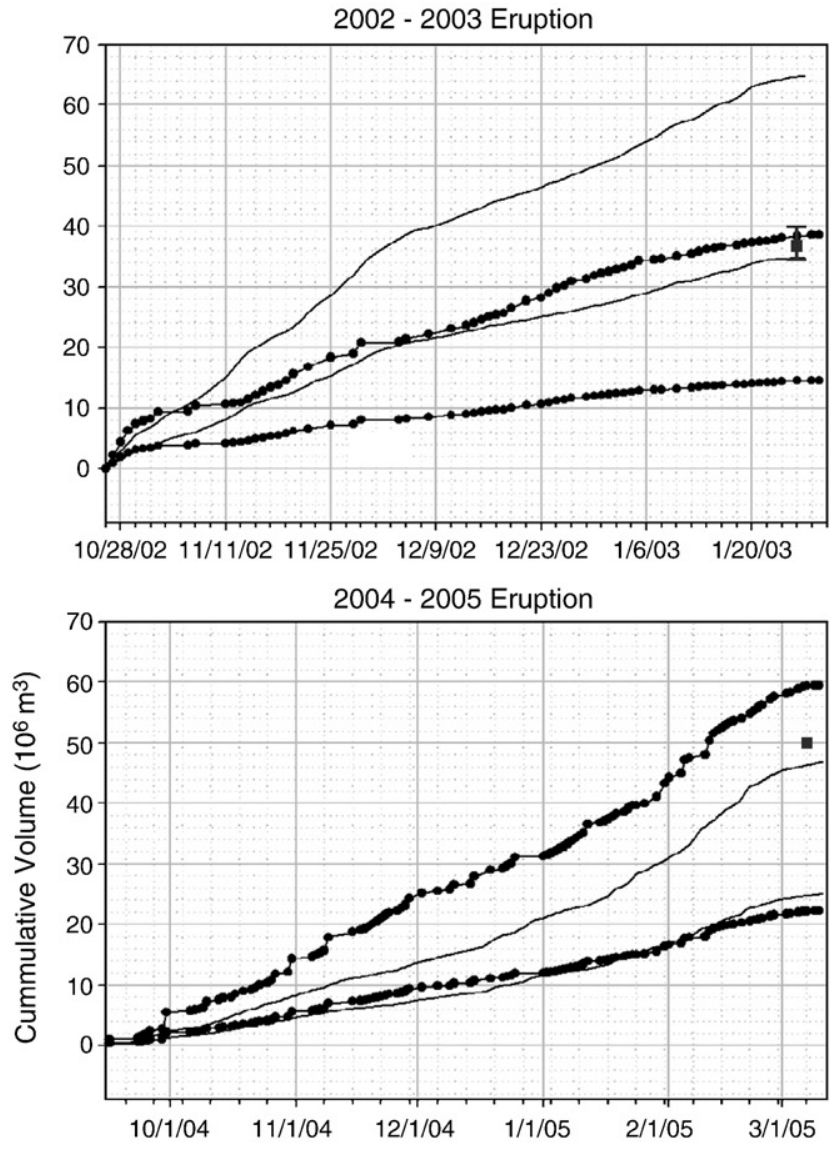

2006 Eruption

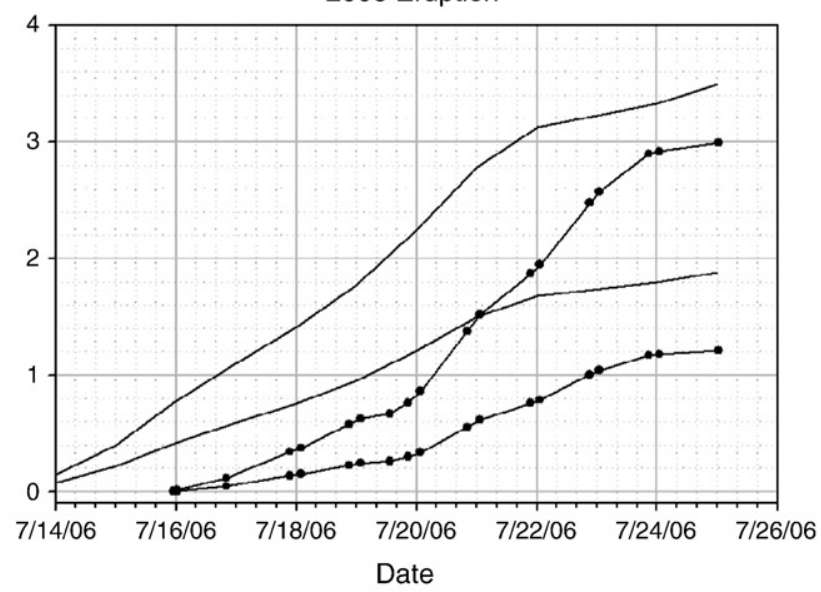

$\begin{array}{ll}- & \text { Degassed Magma } \\ \rightarrow & \text { Erupted Lava }\end{array}$

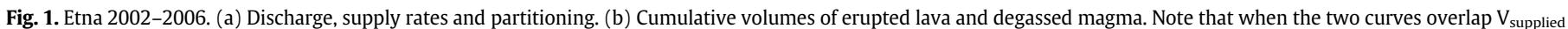

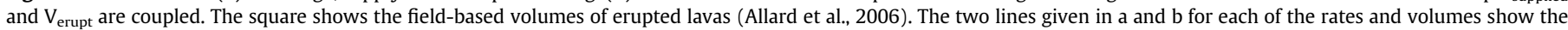
derived upper and lower bounds calculated for each technique.

greater than $\mathrm{V}_{\text {erupt }}$ during Phase $\mathrm{X}$, but less than $\mathrm{V}_{\text {erupted }}$ during Phase $\mathrm{Y}$ (Fig. 1b; Table 3).

\section{Discussion}

The three eruptions encompass the three different volume balance scenarios: i.e.(1) $\mathrm{V}_{\text {supplied }}=\mathrm{V}_{\text {erupt }}$, (2) $\mathrm{V}_{\text {supplied }}>\mathrm{V}_{\text {erupt }}$, (3)
$\mathrm{V}_{\text {supplied }}<\mathrm{V}_{\text {erupt }}$. When $\mathrm{V}_{\text {supplied }}$ is greater than $\mathrm{V}_{\text {erupt }}$ a portion of the ascending magma reaches a depth at which the magma can degas ( 3-4 km: lithostatic depth) (Caltabiano et al., 2004) but does not erupt. This occurred during Phase IV of the 2002-2003 eruption when $V_{\text {supplied }}$ exceeded $V_{\text {erupt }}$ by $8.7 \times 10^{6} \mathrm{~m}^{3}$ (Fig. $1 \mathrm{~b}$ ). In such a scenario the excess of degassed magma must either be stored in the edifice or be removed from the shallow system to be emplaced at 


\section{Exogenous - Endogenous Volume Partition}

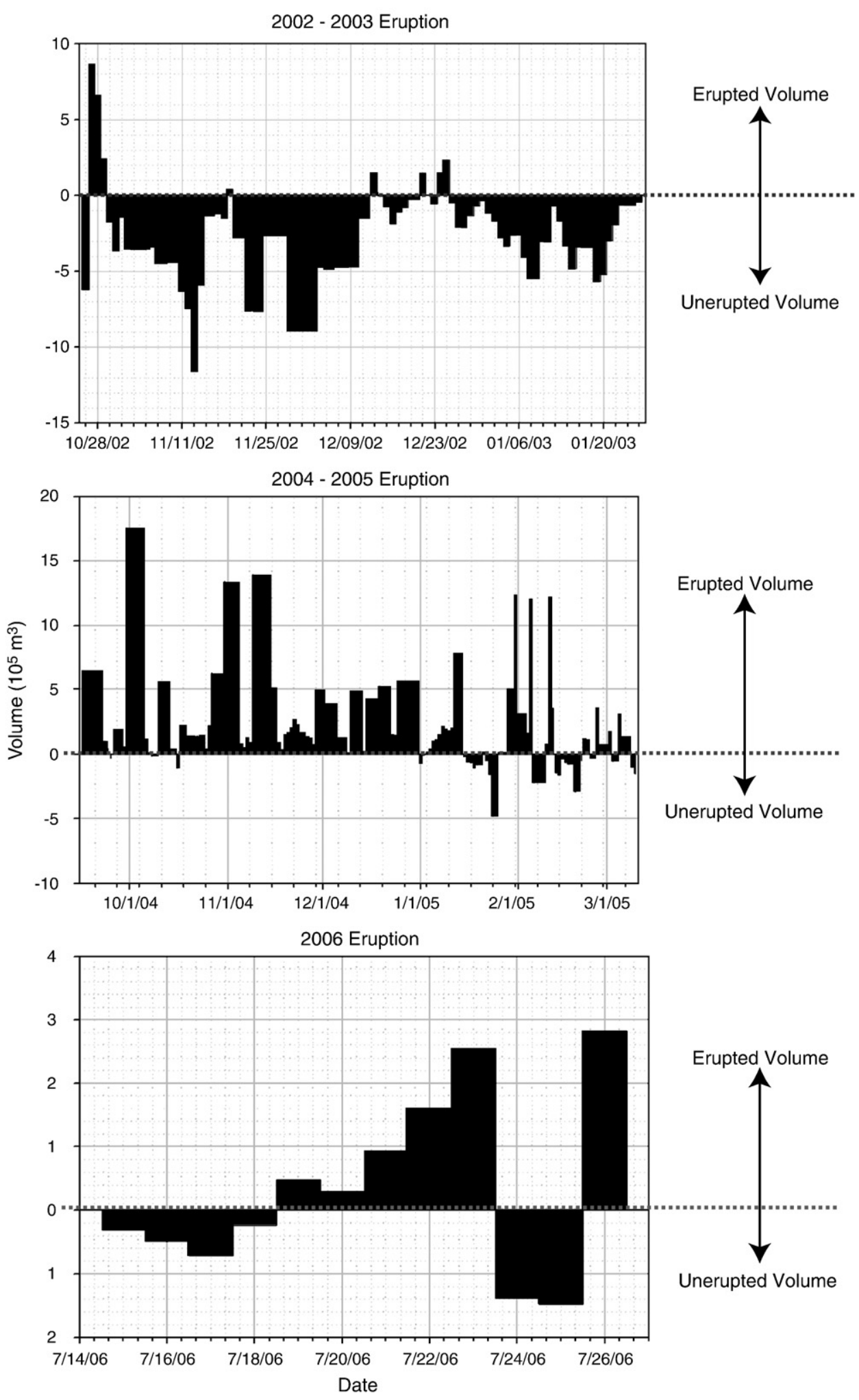

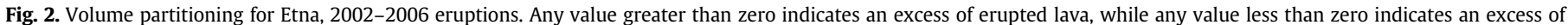
supplied magma.

depth. However, if the magma were erupted explosively the satellite sensor would not be able to detect the emission. Therefore there would be an underestimate in the volume of erupted material. This was the case for Phase II of the 2002-2003 eruption. During that time Etna experienced a highly explosive phase simultaneous with the effusive activity with tephra volumes of up to $2.2 \pm 0.4 \times 107 \mathrm{~m}^{3}$ being erupted (Andronico et al. 2005; Spilliaert et al., 2006). Therefore the difference between the effused and degassed magma $\left(2.9 \times 10^{7} \mathrm{~m}^{3}\right)$ during this phase could be explained by volume lost to tephra. 
Magma may also rise at a rate slower than the gases are able to escape so that degassed magma fluxes can outrun erupted volume fluxes. In such cases the volume of degassed magma will eventually erupt, but will be observed later in the eruption. We use this scenario to account for the volume differences during the 2006 eruption. Early in the eruption $\mathrm{SO}_{2}$ fluxes were elevated, but discharge rates were low $\left(0.4-1.1 \mathrm{~m}^{3} \mathrm{~s}^{-1}\right)$. Later in the eruption, while $\mathrm{E}_{\mathrm{r}}$ reached higher levels $\left(8-4 \mathrm{~m}^{3} \mathrm{~s}^{-1}\right), \mathrm{SO}_{2}$ fluxes remained constant (Fig. 1). This change suggests that magma that had been degassed during the initial phase of the eruption (Phase $\mathrm{X}$ ) had finally reached the surface during the latter phase (Phase $\mathrm{Y}$ ) so that overall $\mathrm{V}_{\text {supplied }}$ and $\mathrm{V}_{\text {erupted }}$ were balanced (Table 3 ).

When $V_{\text {erupt }}$ exceeds $V_{\text {supplied }}$ two different scenarios can occur. Either the excess erupted volume is accounted for by eruption of previously degassed magma, or magma rises from depth at a faster rate than it is able to degas. The first scenario can occur at the beginning of an eruption when magma that has been stagnant within the shallow reservoir becomes incorporated with the eruption of new magma. Etna experiences almost constant degassing at the summit craters, at a time-averaged rate of $\sim 1000 \mathrm{t} / \mathrm{d}$ since the 2001 eruption (Allard et al., 2006). Therefore there is potentially a substantial volume of degassed magma that can reside within the volcano's edifice at most times (Harris et al., 2000). This is available for incorporation with the next eruption. We observe this discrepancy at the onset of the 2004-2005 eruption (Fig. 2). This eruption was preceded by a 20-month period of quiescence and was not preceded by an increase in $\mathrm{SO}_{2}$ emissions (Burton et al., 2005). Thus, time was available to generate a degassed volume that could contribute to the excess volume erupted at the onset of the eruption, in the case of the 2004-2005 eruption this contributed to an excess of $2.6 \times 10^{6} \mathrm{~m}^{3}$ of lava. The second scenario can occur during eccentric eruptions in which magma that feeds the eruption ascends rapidly and bypasses the central conduit (Andronico et al., 2005; Spilliaert et al., 2006). This scenario is observed during Phase I of the 2002-2003 eruption when an excess of $4.3 \times 10^{6} \mathrm{~m}^{3}$ was erupted in the first five days. Therefore at the onset of the eruption a large volume of magma was able to erupt without having adequate time to degas.

\section{Conclusions}

Typically $\mathrm{SO}_{2}$-derived volumes of degassed magma have been used to calculate volumetric budgets of volcanoes on time scales of years to decades. On such a time scale we find that during Etna's three eruptions of 2002-2006 there was a volumetric imbalance, with $2.3 \times 10^{7} \mathrm{~m}^{3}$ of the degassed volume being unerupted (i.e. $24 \%$ of the magma supplied to the shallow system remained unerupted). However, over the time-scale of days-to-weeks we find that partitioning can vary within single eruptions. Once magma reaches a depth where sulfur exsolves several scenarios can occur: (1) the magma can erupt (sometimes incorporating excess volumes of previously degassed magmas), (2) it can remain within the edifice resulting in endogenous growth, or (3) it can be recycled (and perhaps intruded beneath the edifice). During an eruption lasting just a few weeks, all three scenarios can be encountered. During 20022006 , over a total of 280 days of eruptive activity, only on 141 days did the supplied volume couple with the erupted volume. Therefore, only during $50 \%$ of the time were the gas-based and satellite-based measurements coupled. This does not mean that either measurement is in error, but instead points to different processes that control the volume partitioning. Several processes can cause these volumetric imbalances: (1) magma can be rising at a faster rate than it is able to degas $\left(\mathrm{V}_{\text {supply }}<\mathrm{V}_{\text {erupt }}\right)$; (2) magma is erupted in an explosive manner $\left(\mathrm{V}_{\text {supply }}>\mathrm{V}_{\text {erupt }}\right)$; (3) degassed magma is not erupted $\left(\mathrm{V}_{\text {supply }}>\mathrm{V}_{\text {erupt }}\right)$; or (4) the eruption of previously degassed magma occurs $\left(\mathrm{V}_{\text {supply }}<\mathrm{V}_{\text {erupt }}\right)$.

\section{References}

Allard, P., 1997. Endogenous magma degassing and storage at Mount Etna. Geophys. Res. Lett. 24 (17), 2219-2222.

Allard, P., Behnke, B., D'Amico, S., Neri, M., Gambino, S., 2006. Mount Etna 1993-2005: Anatomy of an evolving eruptive cycle. Earth Science Reviews 78 (1-2), 85-114.

Andronico, D., Branca, S., Calvari, S., Burton, M., Caltabiano, T., Corsaro, R.A., Carlo, P.D., Garfi, G., Lodato, L., Miraglia, L., Mure, F., Neri, M., Pecora, E., Pompilio, M., Salerno, G., Spampinato, L., 2005. A multi-disciplinary study of the 2002-2003 Etna eruption: insights into a complex plumbing system. Bull. Volcanol. 67, 314-330.

Andronico, D., Spinetti, C., Cristaldi, M.F., Buongiorno, M.F., 2009. Observations of Mt Etna volcanic ash plumes in 2006: an integrated approach from ground-based and polar satellite NOAA-AVHRR monitoring system. Journal of Volcanology and Geothermal Research 180, 135-147.

Behncke, B., Neri, M., Nagay, A., 2005. Lava flow hazard at Mount Etna (Italy): new data from GIS-based study. Geol. Soc. Am. Spec. Pap. 396, 189-209.

(BGVN), B.o.G.V.N., 2006. Etna. Smithsonian Institute. Bulletin of Global Volcancanism Network 31 (07).

Bjornsson, A., Johnsen, G., Sigurdsson, S., Thorbergsson, G., 1979. Rifting of the plate boundary in North Iceland 1975-1978. J. Geophys. Res. 84 (B6), 3029-3039.

Bonaccorso, A., Bonforte, A., Gugielmino, G., Palano, M., Puglisi, G., 2006. Composite ground deformation pattern forerunning the 2004-2005 Mount Etna eruption. Journal of Geophysical Research 1111 (B12207).

Budetta, G., Carbone, D., 1998. Temporal variations in gravity at Mt Etna (Italy) associated with the 1989 and 1991. Bulletin of Volcanology 59, 311-326.

Burton, M.R., Neri, M., Andronico, D., Branca, S., Caltabiano, T., Calvari, S., Corsaro, R.A., Del Carlo, P., Lanzafame, G., Lodato, L., Miraglia, L., Salerno, G., Spampinato, L., 2005. Etna 2004-2005: an archetype for geodynamically-controlled effusive eruptions. Geophys. Res. Lett. 32, L09303. doi:10.1029/2005GL022527.

Caltabiano, T., Romano, R., Budetta, G., 1994. $\mathrm{SO}_{2}$ flux measurements at Mount Etna (Sicily). J. Geophys. Res. 99 (D6), 12,809-12,819.

Caltabiano, T., et al., 2004. Volcanic gas emissions from the summit craters and flanks of Mt. Etna, 1987-2000. In: Calvari, S., Bonaccorso, A., Coltelli, M., Del Negro, C. Falsaperla, S. (Eds.), Mt. Etna, Volcano Laboratory. American Geophysical Union Geophysical Monograph, pp. 111-128.

Coppola, D., Piscopo, D., Staudacher, T., Cigolini, C., 2010. Lava discharge rate and effusive pattern at Piton de la Fournaise for MODIS data. Journal of Volcanology and Geothermal Research 184 (1-2), 174-192.

Dozier, J., 1981. A method for satellite identification of surface temperature fields of subpixel resolution. Remote Sens. Environ. 11, 221-229.

Dvorak, J.J., Dzurisin, D., 1993. Variations in magma supply rate at Kilauea Volcano, Hawaii. J. Geophys. Res. 98 (B12), 22,255-22,268.

Dzurisin, D., Koyanagi, R.Y., English, T.T., 1984. Magma supply and storage at Kilauea volcano, Hawaii, 1956-1983. J. Volcanol. Geotherm. Res. 21, 177-206.

Francis, P., Oppenheimer, C., Stevenson, D., 1993. Endogenous growth of persistently active volcanoes. Nature 366, 554-557.

Galle, B., et al., 2002. A miniaturised ultraviolet spectrometer for remote sensing of $\mathrm{SO} 2$ fluxes: a new tool for volcano surveillance. Journal of Volcanology and Geothermal Research 119, 241-254.

Harris, A.J.L., Stevenson, D., 1997. Magma budgets and steady-state activity of Vulcano and Stromboli. Geophysical Research Letters 24, 1043-1046.

Harris, A.J.L., Baloga, S., 2009. Lava discharge rates from satellite-measured heat flux. Geophysical Research Letters 36 (L19302). doi:10.1029/2009GL039717.

Harris, A.J.L., Blake, S., Rothery, D.A., 1997. Chronology of the 1991 to 1993 Mount Etna eruption using advanced very high resolution radiometer data: implications for real-time thermal volcano monitoring. J. Geophys. Res. 11102 (B4), 7985-8003.

Harris, A.J.L., Flynn, L.P., Rothery, D.A., Oppenheimer, C., Sherman, S.B., 1999. Mass flux measurements at active lava lakes: implications for magma recycling. J. Geophys. Res. 104 (B4), 7117-7136.

Harris, A.J.L., Murray, J.B., Aries, S.E., Davies, M.A., Flynn, L.P., Wooster, M.J., Wright, R. Rothery, D.A., 2000. Effusion rate trends at Etna and Krafla and their implications for eruptive mechanisms. J. Volcanol. Geotherm. Res. 102, 237-270.

Harris, A.J.L., Dehn, J., Calvari, S., 2007. Lava effusion rate definition and measurement: a review. Bulletin of Volcanology 70 (1)

Harris, A.J.L., Favalli, M., Steffke, A., Fornaciai, A., Boschi, E., 2010. A relation between lava discharge rate, thermal insulation, and flow area set using lidar data. Geophysical Research Letters 37 (L20308). doi:10.1029/2010GL044683.

Kazahaya, K., Shinohara, H., Saito, G., 1994. Excessive degassing of Izu-Oshima volcano: magma convection in a conduit. Bulletin of Volcanology 56 (3), 207-216.

Lautze, N.C., et al., 2004. Pulsed lava effusion at Mount Etna during 2001. Journal of Volcanology and Geothermal Research 137 (1-3), 231-246.

Mazzarini, F., et al., 2005. Morphology of basaltic lava channels during the Mt. Etna September 2004 eruption from airborne laser altimeter data. Geophysical Research Letters 32 (L04305). doi:10.1029/2004GL021815.

Metrich, N., Allard, P., Spilliaert, N., Andronico, D., Burton, F., 2004. 2001 flank eruption of the alkali- and volatile-rich primitive basalt responsible for Mount Etna's evolution in the last three decades. Earth Planet. Sci. Lett. 228, 1-17. doi:10.1016/j. espl.2004.09036.

Neri, M., et al., 2006. Continuous soil radon monitoring during the July 2006 Etna eruption. Geophysical Research Letters 33 (L24316).

Oppenheimer, C., 1991. Lava flow cooling estimated from Landsat Thematic Mapper infrared data: the Lonquimay eruption (Chile, 1989). J. Geophys. Res. 96 (B13) 21865-21878

Spilliaert, N., Allard, P., Metrich, N., Sobolev, A.V., 2006. Melt inclusion record of the conditions of ascent, degassing, and extrusion of volatile-rich alkali basalt during 
the powerful 2002 flank eruption of Mount Etna (Italy). J. Geophys. Res. 111 (B043203). doi:10.1029/2005JB003934.

Stoiber, R., Williams, S., Malinconico, L., 1983. Use of correlation spectrometer at volcanoes. In: Tazieff, H., Sabrous, J.C. (Eds.), Forecasting volcanic events. Elsevier, New York, NY, p. 635.

Sutton, A.J., Elias, T., Gerlach, T.M., Stokes, J.B., 2001. Implications for eruptive processes as indicated by sulfur dioxide emissions from Kilauea Volcano, Hawaii, 1979-1997. J. Volcanol. Geotherm. Res. 108, 283-301.

Williams-Jones, G., Rymer, H., Rothery, D.A., 2003. Gravity changes and passibe degassing at the Masaya caldera complex, Nicaragua. Journal of Volcanology and Geothermal Research 123 (1-2), 137-160.
Witter, J.B., Kress, V.C., Delmelle, P., Stix, J., 2004. Volatile degassing, petrology and magma dynamics of the Villarrica Lava Lake, southern Chile. Journal of Volcanology and Geothermal Research 134, 303-337.

Wright, R., Blake, S., Harris, A.J.L., Rothery, D.A., 2001. A simple explanation for the space-based calculation of lava eruption rates. Earth and Planetary Science Letters 192, 223-233.

Yang, K., et al., 2007. Retrieval of large volcanic SO2 columns from the Aura Ozone Monitoring Instrument: Comparision and limitations. Journal of Geophysical Research 112 (D24S43). doi:10.1029/2007JD008825. 